\title{
Silvopastoral System in Morocco: Focus on Their Importance, Strategic Functions, and Recent Changes in the Mediterranean Side
}

\author{
Youssef Chebli ${ }^{1,2, *(\mathbb{D}}$, Samira El Otmani ${ }^{1}{ }^{(1)}$, Fouad Elame $^{3}$, Nassim Moula ${ }^{2}{ }^{(}$, Mouad Chentouf ${ }^{1}(\mathbb{D}$, \\ Jean-Luc Hornick ${ }^{2}$ (D) and Jean-François Cabaraux ${ }^{2}$ (I)
}

1 Regional Center of Agricultural Research of Tangier, National Institute of Agricultural Research, Avenue Ennasr, BP 415 Rabat Principale, Rabat 10090, Morocco; samira.elotmani@inra.ma (S.E.O.); mouad.chentouf@inra.ma (M.C.)

2 Department of Veterinary Management of Animal Resources, FARAH, Faculty of Veterinary Medicine, University of Liège, Avenue de Cureghem 6, B43, 4000 Liège, Belgium; nassim.moula@uliege.be (N.M.); jlhornick@uliege.be (J.-L.H.); jfcabaraux@uliege.be (J.-F.C.)

3 Regional Center of Agricultural Research of Agadir, National Institute of Agricultural Research, Avenue Ennasr, BP 415 Rabat Principale, Rabat 10090, Morocco; fouad.elame@inra.ma

* Correspondence: youssef.chebli@inra.ma

check for updates

Citation: Chebli, Y.; El Otmani, S.; Elame, F.; Moula, N.; Chentouf, M.; Hornick, J.-L.; Cabaraux, J.-F. Silvopastoral System in Morocco: Focus on Their Importance, Strategic Functions, and Recent Changes in the Mediterranean Side. Sustainability 2021, 13, 10744. https://doi.org/ $10.3390 /$ su131910744

Academic Editor: Pablo Peri

Received: 30 July 2021

Accepted: 24 September 2021

Published: 27 September 2021

Publisher's Note: MDPI stays neutral with regard to jurisdictional claims in published maps and institutional affiliations.

Copyright: (C) 2021 by the authors Licensee MDPI, Basel, Switzerland. This article is an open access article distributed under the terms and conditions of the Creative Commons Attribution (CC BY) license (https:/ / creativecommons.org/licenses/by/ $4.0 /)$.

\begin{abstract}
In the Mediterranean basin, the silvopastoral system has always been part of the regional economy. Silvopastoral areas contribute significantly to the development of the ecological and socioeconomic factors of territorial sustainability. However, little attention has been paid to reviewing the importance, historical evolution, socio-economic conditions, and climate change impact of the southern Mediterranean region of northern Morocco. This review casts light on research on the silvopastoral systems in Morocco with a focus on the Mediterranean side. Sixty-nine peer-reviewed publications were selected for this systematic review. The findings revealed that silvopastoral areas play a very important role in animal feeding in Morocco. Animals are managed traditionally on these woodlands where they graze throughout the year. The silvopastoral system has undergone several changes over recent decades. These changes have had a direct impact on ecosystems, causing a decline in biodiversity, forest degradation, and an increase in land use at the expense of silvopastoral areas, mainly in the Mediterranean region of northern Morocco. Consequently, the sustainability of the silvopastoral systems would undoubtedly be negatively affected. The review finishes with some crucial strategies and propositions that could be encouraged to support sustainable management actions of silvopastoral resources. In the conclusion, we outline the need to assess the realistic socioeconomic and ecological benefits of silvopastoral systems to promote their sustainable development.
\end{abstract}

Keywords: silvopastoral; Mediterranean region; sustainability; northern Morocco; grazing; forest

\section{Introduction}

A silvopastoral system is a productive arrangement characterized by a combination of pastures and trees in the same area in order to increase the profitability of the system through the diversification of products while preserving the natural environment. It is considered a sustainable method of restoring degraded pastures [1]. The silvopastoral system is identified by at least three components, usually pasture, trees, and livestock. Farmers and different users are solely responsible for the sustainable functioning of the silvopastoral system [2,3]. Between these different components, both ecological and economic interactions are created. An ecological interaction becomes beneficial when the silvopastoral system shows evidence of an increase in yield per unit area and sustainable use of resources with an improvement in environmental aspects.

The exploitation of silvopastoral resources, through the use of forest vegetation, not only provides tangible products such as wood, forage, medicinal plants, food, and feed, 
but also intangible products such as biodiversity improvement [4]. The major limitations of silvopastoral areas are the potential competition between trees and pastures for light, water, and nutrients, as well as the growing needs of the population for agricultural land and natural resources.

In the Mediterranean basin, topography, climate, and vegetation types are favorable for silvopastoral activities. The Mediterranean silvopastoral system, more than elsewhere, could be considered a better example of extensive farming systems, which are characterized by a strong integration of livestock, agriculture, and forestry into the family farm [5]. The animals are managed in a traditional way on these lands where they browse woody and herbaceous vegetation. The Spanish "dehesa", which means pasture in castellan or "montado" in Portuguese, is a communal domain composed of a pasture in the undergrowth located at the level of the Iberian Peninsula [6]. This forest pasture represents one of the most successful examples of silvopastoral systems in the Mediterranean region. The aim of this literature review is to analyze the importance and evolution of Moroccan silvopastoral systems with a focus on the southern Mediterranean region of northern Morocco, as well as how to support their sustainability.

In this review, we analyze, at the national scale, the importance of silvopastoral systems, their historical evolution, socio-economic conditions, and climate change impacts. Then, we focus on the southern Mediterranean region of northern Morocco where we explore the useful strategic functions of silvopastoral areas and drivers of the observed changes. In the end, we present certain crucial development programs that could be more encouraged to support sustainable management actions of silvopastoral resources.

\section{Methods}

In order to meet the goal of this study, the top scientific literature was searched, based principally on the recent and significant research carried out in the field. This literature review was conducted according to the Preferred Reporting Items for Systematic Reviews and Meta-Analyses (PRISMA) guidelines that involve several steps [7]. Because the study also concerned the temporal evolution of silvopastoral areas, the databases were searched for papers dating from 1980 to 2021. All papers that are not peer-reviewed were excluded. A search was performed on 20 May 2021 using the following key terms: "Morocco" OR "northern Morocco" OR "Mediterranean region" AND "silvopastoral" OR "silvopastoral system" OR "silvopastoral area" OR "forest" OR "forest rangeland" OR "forest pasture" AND "livestock" OR "Animal production". Mendeley software and Microsoft Excel were used as assistant tools for recording relevant data. The search terms were applied to the title, abstract, and keywords. Regarding statistical data, they were collected from FAOSTAT and MAPMDREF (Ministry of Agriculture, Maritime Fishing, Rural Development, Water and Forests) databases.

The initial literature search returned a total of 834 documents after duplicates were removed. However, the screening of documents based on the titles indicated that 77 documents concern other countries than Morocco. An additional 667 documents were excluded following scrutiny of the abstracts as they did not meet one or more of the inclusion criteria. Finally, 36 documents were discarded following the analysis of the full texts. Therefore, 54 documents were selected for the systematic review; these included 37 journal articles, 12 book chapters, and 5 proceedings papers. Figure 1 displays the article selection process following the PRISMA methodology. 


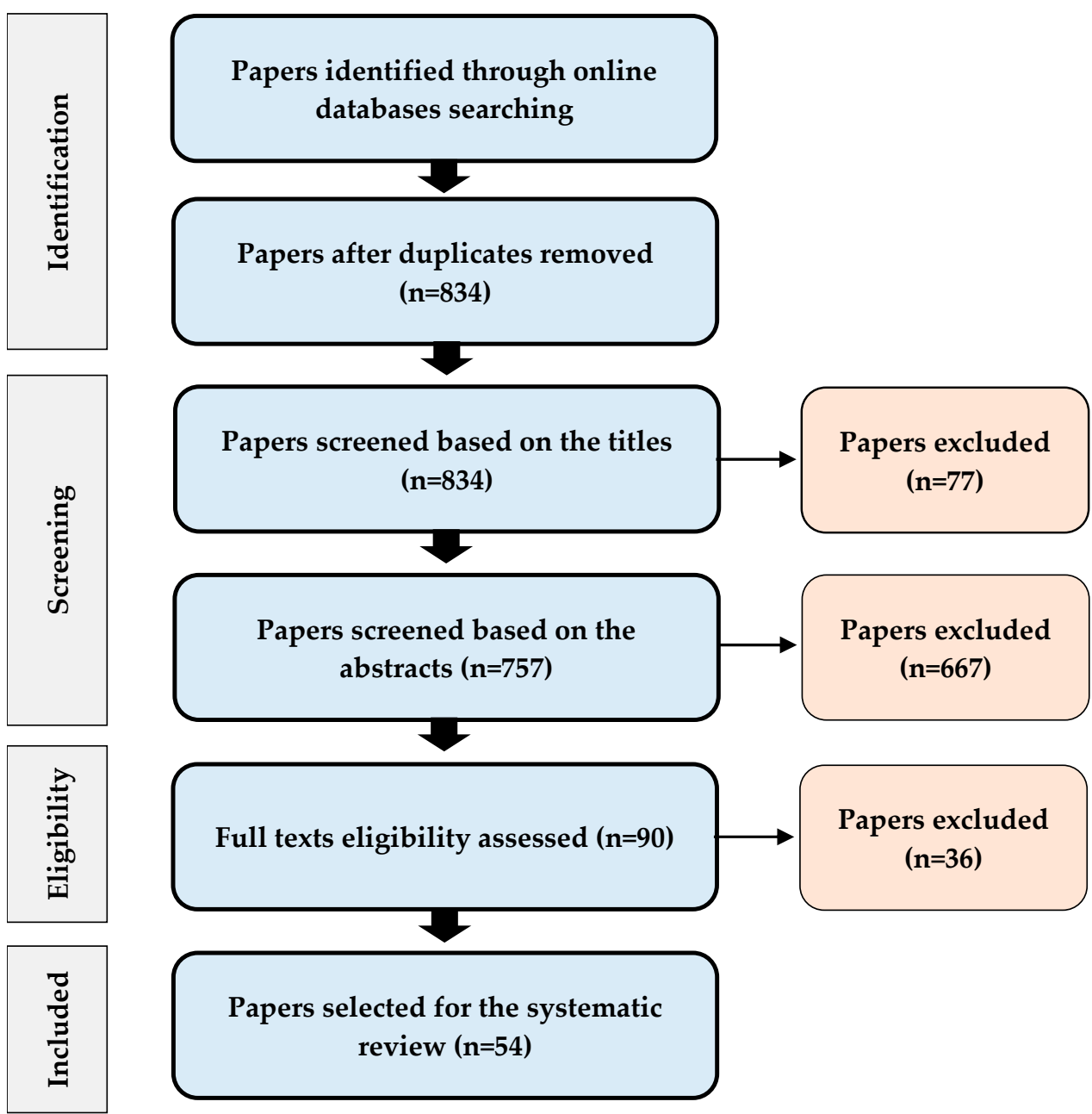

Figure 1. Systematic review process.

\section{Results and Discussion}

\subsection{Moroccan Silvopastoral System}

\subsubsection{Forest Importance and Evolution}

Forest ecosystems are dominated by trees and made up of biologically integrated communities of plants, animals, and microbes, as well as the soils and atmospheres with which they interact [8].

In Morocco, the forest area is about 9 million ha, including Stipa tenacissima steppes, representing around $30 \%$ of rangelands. The most important silvopastoral formations are the holm oaks, the argan groves, the suberries, the juniper groves (especially the red juniper of high mountains), the Stipa tenacissima steppes, the sagebrush steppes, and the saharian Acacia formations. Silvopastoral areas provide 1.5 to 2 billion forage units per year, which represent $17 \%$ of the diet requirements of livestock, and can reach up to $80 \%$ of forest areas of northern Morocco and High Atlas (central Morocco). Eight million heads, i.e., approximately $32 \%$ of the national herd, browse throughout the year in silvopastoral areas [9]. The socio-economic dimension is also quite useful, with rural populations highly dependent on the forest and its derived products (around 7 million people) [10]. Like all forest ecosystems, Moroccan forests have considerable ecological and socio-economic advantages. They indeed perform several ecological functions such as regulation of the water regime, protecting soil erosion, combatting desertification, biodiversity conservation, etc. This vital ecological function is coupled with significant socio-economic value. In addition to its contribution to the creation of wealth, jobs, and income, the forest is an essential component of tourism and recreational activities. 
In the past, grazing animals in the forest were undertaken according to a certain organization form, which led to the use of silvopastoral areas in relatively well-defined seasons: Transhumance periods, delimbing during cold periods, browsing in spring, and imposing temporary protections to regenerate and improve the browsed pasture. However, destructive processes prevent the best function of forest ecosystems. These destructive processes are due to the combination of several factors such as forest ecosystem instability, overgrazing, the decrease in transhumance, and forest overuse.

In fact, the Moroccan forest is experiencing increasing pressure in terms of human, pastoral, and land use that could be explained by an absence of organizational rules, which negatively impacts the conservation and regeneration of silvopastoral lands. Indeed, population growth and the decrease in grazing areas in favor of agriculture activities have led to a lack of respect of the traditional and common pastoral practices [11].

For decades, mountainous areas were the focus of development strategies, where natural and cultural heritage were the main concern of environmental and socio-economic orientations [12]. The high anthropic pressure, the overexploitation of silvopastoral resources as well as drought conditions have incited populations to set up traditional forms of forest and pastoral area control [13]. These regimes are called "Agdal", a term that defines a collective silvopastoral territory subject to temporary protections. It corresponds to the temporary protection scheme of a resource space by traditional institutions operating at different territorial scales (village, tribe) [14]. In the High Atlas, this practice allows the preservation of natural resources. Nowadays, this traditional community management system of silvopastoral resources is finding new success with the generalization of the sustainable development concept (enhancement of local knowledge, participative management of natural resources, etc.) [13].

\subsubsection{Socio-Economic Conditions}

The grazing concept is linked to land for which the boundaries are precisely delimited, called a territory; pastoralism is made up of human relationships between users (historically by nomadic societies). These human relationships always have a traditional setting for a territory corresponding to a given human group [15]. This concept of territory is so important that it reappears immediately with force when conflict arises over cultivated areas or rangelands and manages relations between the group belonging to that territory and foreigners herding their animals at a certain period of the year. In fact, seasonal transhumance, most often limited to herding societies driven by local climate conditions and the presence of grazing lands, is directly concerned with the limits of the territory. We generally speak of nomadic or almost exclusive nomads, whose long trajectories follow an annual cycle influenced by the great cold of winter and drought conditions of pre-Saharan summer [16].

Moroccan societies are characterized by the presence of traditional management forms "jema $\hat{a}$ " whose functioning is provided by representatives of the ethnic groups" "naib". In terms of silvopastoral resource management, these "naibs" are more or less functional depending on the area [17]. Pastoral associations and cooperatives created in recent decades are also contributing to the participatory management of pastoral areas, including forest resting and protection.

Generally, the socio-economic characteristics and living conditions of rural populations in Morocco are relatively harsh and have become unfavorable with the recent years of drought. Indeed, the increasing population growth and forest degradation create a great imbalance between population and resources in a bioclimatic context, which does not allow an optimal increasing of forest productivity [12].

\subsubsection{Animal Production and Silvopastoral System}

The animal production value chains play a key role in the economic, social, and nutritional sectors. They provide $38 \%$ of the turnover of the agricultural sector, $60 \%$ of jobs in agriculture, and contribute to the guarantee of food security of the country. National 
animal production covers approximately $87 \%$ of the milk demand, $98 \%$ of red meats, and $100 \%$ of white meats [18]. Generally, silvopastoral systems in Morocco are complex and use complementarity feeding resources from various origins of the silvopastoral environment (forest and shrubland).

In Morocco, there are two distinguished animal production systems related to the forest rangeland: Silvopastoral and agro-silvopastoral systems. The silvopastoral system consists of forest grazing by ruminants, thus exploiting spontaneous resources growing under trees, fallen fruits and nuts, and leaves of trees, to produce meat and/or milk. It is a combination of trees, pastures, and herbivore livestock in the same place with reciprocal benefits that contribute to the farmer's benefits and, at the same time, protecting the ecosystem [19-21]. The silvopastoral system is specific to mountain regions covered with forests. Agro-silvopastoral systems are found in the hills and mountains. However, agriculture is added to the silvopastoral system combination (trees, pastures, and livestock). In this system, agricultural, silvopastoral, and pastoral resources are complementarily and rationally exploited according to the territories' ecological and geographical differences. Contrary to the agro-silvopastoral system, the agricultural component remains limited or almost non-existent in herd feeding in the silvopastoral system [22]. Both systems ensure meat and/or milk production with low charges and inputs because the forest provides grass and tree fodder species, as well as shade that reduces heat stress [21]. In addition, the grazing of forests by ruminants could contribute to silvicultural interventions such as cleaning the undergrowth, better circulation, and structuring of the space. These systems, especially in arid areas, play essential economic, social, and environmental roles, by reducing poverty and ensuring food security and sustainable livelihoods, and by improving the environmental sustainability and the resilience of territories or landscapes.

The farming practiced in agro-silvopastoral and silvopastoral systems is extensive, composed mainly of small ruminants of rustic local breeds well adapted to their environment, owned by a majority of small breeders, and poorly organized and supervised [23]. Ten million ruminant heads ( $40 \%$ of the national livestock), composed of 5.2 million sheep (31\% of the national sheep livestock), 4 million goats ( $70 \%$ of the national goats' livestock), and 0.8 million cattle ( $32 \%$ of the national cattle livestock), are grazing forest rangelands in silvopastoral systems [24]. In this system, the most important livestock farming practiced in the forest is represented by a herd of small ruminants of rustic local breeds led in an extensive mode of farming. The silvopastoral systems are found in mountainous areas, especially in the Middle Atlas, the northern region (Rif), and the Southwest (Argan agroves) [23]. In the Middle atlas rangeland, holm oak is most abundant, followed by cedar formations, and the main livestock farming is the extensive type based on Timahdit sheep that represent $88 \%$ of the ruminants [22,23]. The argan tree (Argania spinosa) formations located in southwestern Morocco are spread over 870,000 ha, where goats are the dominant herd because of their grazing adaptation capacity, with 1 million heads. The number of sheep browsing in argan formations is about 0.5 million heads. The foliage of the argan tree contributes $30 \%$ of the pastoral production that is estimated at $200 \mathrm{UF} / \mathrm{Ha}$ in a normal year (between 90 and 240 UF) corresponding to 174 million UF [25]. In northern Morocco, forest areas largely contribute to the regular feeding of mainly goat herds throughout the year [26].

\subsubsection{Changes in Social Patterns and Production Systems}

Facing accelerated socio-economic and demographic changes as well as the transformation of traditional institutions and pastoral territorial dynamics, several constraints are hindering the improvement of the Moroccan silvopastoral system.

\section{A. Dependance of livestock system on pasture}

In addition to the various practices related to forest exploitation, farming system efficiency remains very uncertain due to the high cost of complementary feeds and the drop in market selling prices of livestock during drought. Thus, we observe overexploitation of 
silvopastoral resources upstream of the chain value and low productivity of the extensive livestock farming at the market level [27,28].

B. Territorial dynamics and transformations

Overgrazing is exacerbated by changes in rangelands management practices. This has indeed undergone deep mutations linked, in particular, to the practice of "Agdal" ceasing, which is based on the grazing defense practice in the high peaks of mountains before the summer transhumance. The disruption of these transhumance movements by lowland cultivation has reduced rangelands areas, and as a result, we are assisting overgrazing and natural resource depletion, such as deforestation [29].

In silvopastoral areas, grazing animals are increasingly challenged by their mobility limitation due to agricultural expansion [30]. This turns into overgrazing, marked mainly by a localized usage of pastures (herds being concentrated in the same place for a long time). This situation leads to the emergence of degraded areas and unpalatable species [31].

C. Changes in production systems

Several factors are involved in the transformation of production systems [18]:

- Production intensification tendency: High production of milk and meat requires a good quality of varied breeds and an important demand for inputs (feed supplementation);

- Drought: The effects of drought play a crucial role in changing farming practices that usually depend on natural resources (rangelands), such as a trend towards the establishment of fodder reserves (more forage crops), purchasing more animal feed, and a reduction in the number of livestock;

- Herd mobility regression: For several decades, herd mobility, which ensured the sustainability of pastoral resources, has strongly regressed due to a decrease in the herd size of small and medium breeders who were following water points and croplands affected by the recurrent droughts of the past three decades, the clearing of the best rangelands, and the breakdown of the social structures and traditional institutions responsible for the management of pastoral resources;

- Poor availability of water (watering): Rangelands are characterized by an insufficient network of water for livestock watering. This situation is reflected by the reduction in herd performance following movements in search for water and by the poor use of pastoral and silvopastoral areas;

- Weak supervision of breeders: Pastoral and silvopastoral regions are characterized by insufficient supervision of breeders, resulting in poor livestock performance. In addition to that, the lack of strategies that take climate risk into account contributes to the vulnerability of livestock systems.

\subsubsection{Climate Change Impacts}

Silvopastoral areas are very sensitive to climate change. This has been shown by past observations, experimental studies, and simulation models based on current physiological and ecological understanding [32-34]. According to many authors, the various changes in the normal course of the climate would therefore be the cause of various damages in ecosystems, in particular southern Mediterranean forest ecosystems. In fact, climate change has led to a warming of the atmosphere, changes in rainfall patterns, and extreme events such as droughts, floods, and forest fires becoming more frequent. Since the late 1970s, the occurrence of drought years has increased in Morocco, presenting a major constraint for the country's future economic and agricultural developments. Morocco is currently experiencing the longest dry period in its modern history, which is characterized by a decrease in precipitation and a clear trend of rising temperatures. This fact is also confirmed by many authors who predict a decrease in surface runoff and precipitation and an increase in temperatures [35-37].

Morocco's future climate forecasts predict an increasing trend in the annual average temperature, ranging from 2 to $3{ }^{\circ} \mathrm{C}$ towards the end of this century; a tendency to reduce the average volume of precipitation; an increase in the frequency and intensity of 
thunderstorms in the north and west of the Atlas Mountains; an increase in the frequency and intensity of droughts in the south and east of the country; a disruption of seasonal precipitation (winter rain concentrated over a short period); and a reduction in the duration of snowfall [38,39]. These impacts will definitely be environmental, with a modification of the distribution areas of the species and therefore of the landscapes, stronger erosion of the soils, increased fire risks, and high vulnerability to insects and diseases. However, they could also be economic and social, characterized by decreased productivity and impoverishment of populations living on natural resources. Similarly, changes in environmental variables such as temperature, precipitation, and relative humidity can influence the emergence of plant diseases and pests. Outbreaks of plant diseases can cause huge losses in crop yields, and also threaten to wipe out some plant species.

The dysfunction of many ecosystems, such as cork groves, cedar forests, and juniper groves, and the extinction of certain vegetation that represent a favorable environment for the installation and development of a rich and diverse flora and fauna have led to the depletion of some species and the disappearance of others. In fact, the Moroccan Rif area lost half of its vegetation cover between 1966 and 1986. Likewise, the vegetation cover of the region of the eastern part experienced a decline of around 23\% between 1975 and 2006. At the national level, the cork forest lost $13 \%$ of its area in 60 years (1938-2000) [40]. In addition, in the southern area of Morocco, the Argan grove, which extends over 830,000 hectares, lost a third of its surface. Its average density decreased from 100 to 30 trees per hectare [41].

Despite their diversity, forest ecosystems in Morocco are highly impacted, due to increased pressure of population growth, the overexploitation of silvopastoral resources, and drought conditions. Indeed, the flora and vegetation of Morocco are subject to very severe ecological conditions and anthropogenic pressure. The anarchic degradation of natural environments has reached alarming levels. In the short and medium term, threats to species and environments are very concerning and are aggravated by the effects of global climate change [40]. According to another study, 45\% of the current Moroccan forest area would be lost by 2050 , despite reforestation efforts, and thus $22 \%$ of the flora and several species of birds and mammals could disappear [42].

\subsubsection{Silvopastoral Management Programs}

In Morocco, forest rangelands represent an area of intersection between the forest as a private domain of the government and the usage rights that are devoted to the neighboring populations (users). This area of intersection will either extend or shrink according to a system that is very influenced by climate variations. Indeed, climatic conditions directly affect the feeding behavior of the livestock through an extension of the period of the stay and an increase in the pastoral biomass load in the forest. The recurrence of droughts will cause abortion of the vegetative cycle of pastoral species, which will not reach maturity, leading to a reduction in the soil seed stock and a loss of pastoral biodiversity. Thus, we are observing a proliferation of unpalatable species to the detriment of palatable species and annuals compared to perennials, which usually explain the extension of the grazing period [31].

Considering the droughts that affect more than $80 \%$ of the national territory, many silvopastoral programs were employed [10]. The National Forest Program was the first sector planning strategy. It therefore represented the strategic framework for sustainable development of the forest sector, which set the forest policy structure to be achieved by 2020. Several "sub-sector" master plans have been drawn up and are currently serving as strategic frameworks for planning activities by the forest authorities. With the creation of the High Commissioner, Office for Water, Forests, and Desert Control (HCEFLCD) in 2004, a new intervention framework was developed, the Ten-Year Program, to implement these instruments through a planning approach focused on results.

In addition to the national program, several partners and organizations are interested in this sector, namely: 
- The German Society for International Cooperation (GIZ) as part of the regional silvaMediterranea project (adapting the framework for forestry policy to meet the needs of climate change in the Middle East and North Africa (MENA) region) from 2010 to 2014 .

- The German bilateral cooperation (BMELV) was also participating (until the end of 2017) in forest conservation and the definition of management methods.

- The French Development Agency (AFD) is involved in environmental protection and adaptation to climate change programs.

- The Food and Agriculture Organization (FAO) intervenes within the framework of a project aiming to reduce poverty and fight desertification.

\subsection{Mediterranean Silvopastoral System of Northern Morocco}

In northern Morocco (Figure 2), the silvopastoral areas (Figure 3), a part of the forest land, are managed and protected by the MAPMDREF. Forests cover an area of 544,291 ha including 475,332 ha and 68,959 ha of natural and artificial formations, respectively. The afforestation rate is about $26 \%$, which classifies the region among the most forested areas of the country [43]. Thanks to its privileged geographical position, northern Morocco has a large part of the terrestrial biodiversity of the Mediterranean basin. It is considered among the 34 zones in the world characterized by both high biodiversity and alarming menace levels [44]. This silvopastoral system is marked by its history, nature, and constraints. It is a multipurpose area characterized by a great diversity of resources, and it plays useful strategic functions at ecological, socio-economic, and pastoral levels.

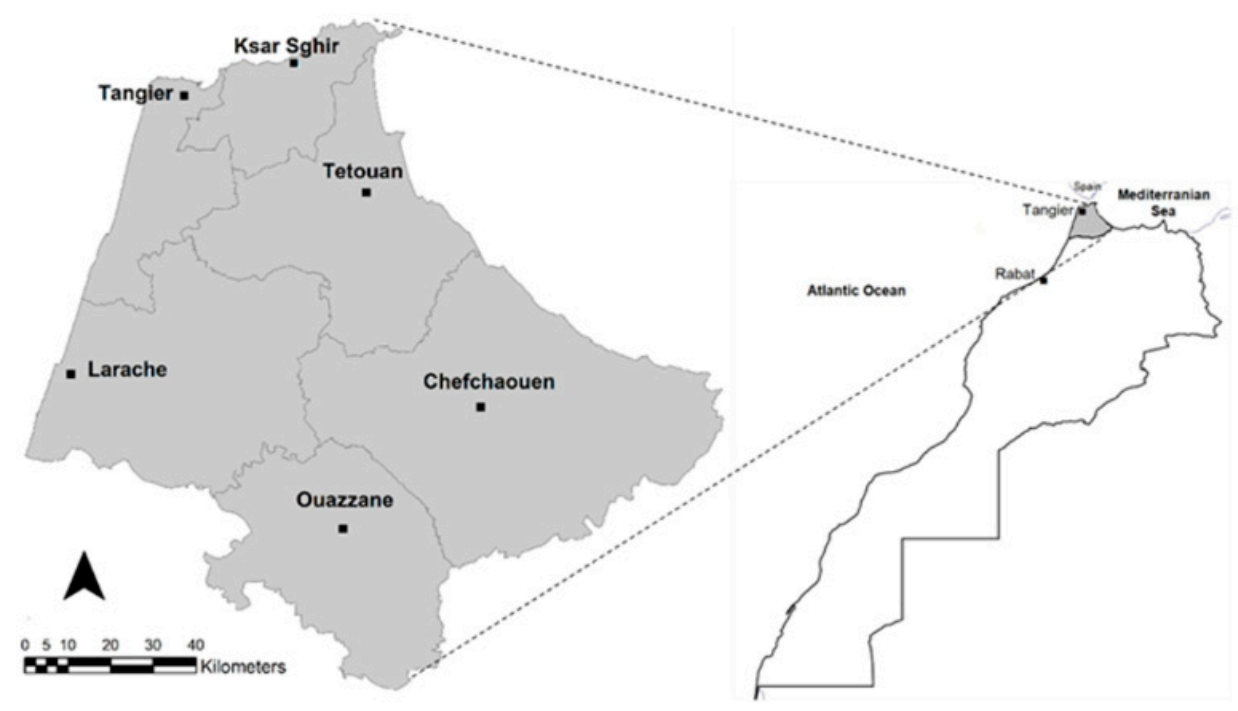

Figure 2. Location of the area covered in the present study (northern Morocco).

\subsubsection{Silvopastoral System Functions}

\section{A. Ecological and environmental functions}

Forest areas of northern Morocco guarantee an important wealth of renewable natural resources. All of the Moroccan natural ecosystem types are represented there, except those of the arid and Saharan areas. It shapes the landscape with rich and varied flora and fauna, and it includes a large number of endemic, rare, or very remarkable species.

Through its special geological features and its privileged geographical location between the Atlantic and the Mediterranean seas, the formation of a mountain barrier in the north of Morocco, the Rif mountains, despite their austere natural environment, constitutes a very rich forest massif in term of biodiversity. They are also attractive and appreciated nationally and internationally [45]. 


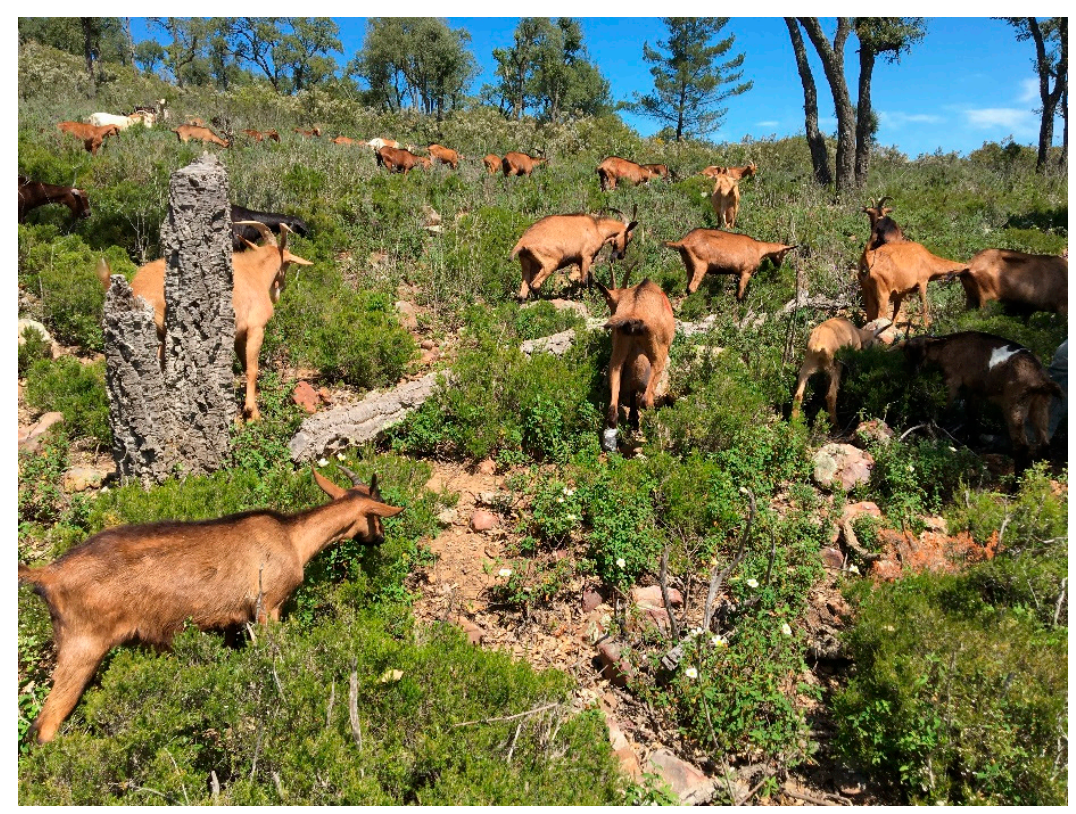

Figure 3. Example of a Mediterranean silvopastoral area in northern Morocco (photo taken in the field by Chebli in 2021).

This silvopastoral area remains an area renowned for its great biodiversity, which has favored the emergence of many forest species and the constitution of multiple ecosystems. The natural vegetation of the massif is mainly conditioned by the topographical nature of the land. There are two sectors: The glacis, the lowest of which is $300 \mathrm{~m}$, and the mountains from $1050 \mathrm{~m}$ up to $2150 \mathrm{~m}$. At an altitudinal amplitude of $1400 \mathrm{~m}$, we meet varied vegetation, including low shrub formations resulting from the degradation of trees.

Northern Morocco testifies to great ecological diversity, represented by an expansive cork grove and dominated by conifers and deciduous trees. There are two main forest areas in the region: Talassemtane (central-western Rif) and Bouhachem (intersection of the provinces of Tetouan, Larache, and Chefchaouen). In the Talassemtane forest area, Quezel et al. [46] described the endemic landscape of the fir forest (Abies pinsapo subsp. Maroccana, Cedrus atlántica, Hacer granatensis, Pinus nigra subsp. Mauritanica, Pinus pinaster subsp. Maghrebiana, and Quercus rotundifolia) as real space of the diversification of forest species in the Maghreb. For the forest area of Bouhachem (Alnus glutinosa, Cedrus atlantica, Pinus pinaster subsp. Maghrebiana, Prunus lusitanicum, Quercus pyrenaica, Q. canariensis, Q. rotundifolia, peat bogs with Sphagnum auriculatum, etc.), it represents an exceptional biological value and an irreplaceable biogeographical interest [47]. The shrub strata are dominated mainly by the following plant species: Arbustus unedo, Cistus crispus, Cistus monspeliensis, Erica arborea, Lavendula stoechas, and Pistacia lentiscus [26].

The cork oak tree is an endemic specie of the Mediterranean basin. Four countries (Portugal, Spain, Algeria, and Morocco) represent 91\% of the world's cork oak trees reserve. This forest species has been present in the western Mediterranean for over 60 million years. In Morocco, the range of the cork forest has been greatly reduced as a result of strong climatic variations, and above all, due to human activities over long periods $[30,48]$.

Forest has a strong impact on the quality of our environment and could be considered a full actor in the management of the environment and natural resources.

The forest contributes to soil maintenance thanks to the root system and the aerial cover (canopy) of plants. The natural erosion of fallow land is accentuated by the torrential precipitation of the Mediterranean climate. One of the most effective protective functions of forests is the reduction of soil water erosion. The forest is considered an area of soil restoration if it is not overexploited. Soil erosion on sloping land is generally of two types, surface erosion and land movement. Forests play a favorable role in both cases. 
Soil losses in the form of sediment loads in runoff and their dynamics during rainy periods also depend on the condition of the soil surface. Under forest cover, compared to other types of plant cover, the limitation of erosion is linked to the delay in the onset of runoff and the slowness of the establishment of the strong runoff regime [49]. Incorrect use of these resources leads to a reduction in plant cover, which results in an accentuation of the phenomenon of erosion. In northern Morocco, the degradation of the plant cover results in a loss of land, annually exceeding $3000 \mathrm{t} / \mathrm{km}^{2}$. This situation is explained by anthropogenic pressure, over the years, exerted on different levels of forest vegetation, in particular, that of the cork oak forest, which covers fertile siliceous soils [50].

The erosion problem in the Rif mountains has been known for more than 50 years, due to population growth, overgrazing, and clearing, which leads to the degradation of plant cover and soil and subsequently to increased runoff, gullying, the undermining of the banks of the wadis, landslides of the surrounding hills, and accelerated sedimentation in the dams. Erosion phenomena are varied and significant: Sheet erosion (1 to $5 \mathrm{t} / \mathrm{ha} /$ year), rill erosion (10 to $100 \mathrm{t} /$ ha/year), gullying (100 to $300 \mathrm{t} /$ ha /year), and movement mass and agricultural erosion (1 to $60 \mathrm{t} / \mathrm{ha}$ /year) [51].

Forests' functions and their influence on microclimatic conditions, regulation of water flows, downstream water availability, and erosion preservation are generally well established at both regional and local scales of landscapes. Populations living in areas with high or partial forest cover are convinced that forests influence local rainfall patterns [52].

Through carbon dioxide sequestration in wood and soil, forests play a direct role in the cycle of the main greenhouse gases. By photosynthesis, plants fix this gas in terrestrial biomass, mainly the forest. This recycling of carbon in the forest is extremely important, since each year, $120 \mathrm{Gt}$ of carbon is exchanged between the earth's atmosphere and vegetation, compared to the $6 \mathrm{Gt}$ of carbon emitted by the combustion of fossil sources. This exchange is never completely balanced, and forests therefore play a positive role in regulating the greenhouse effect [53]. In Morocco in 2010, the carbon stock of living forest biomass was estimated at 256 million tonnes, equivalent to $89 \mathrm{t} / \mathrm{ha}$ [54].

Forest areas, in addition to these functions and vital sources from the environmental perspective, such as soil protection and biodiversity, constitute a shelter for fauna and offer favorable microclimates for the development of herbaceous and abusive strata [55].

\section{B. Socio-economic function}

Moroccan forests contribute $2 \%$ to the agricultural Gross Domestic Product (GDP) and $0.4 \%$ to the national GDP, but its real contribution is estimated at $10 \%$ of the agricultural GDP, if we consider the income drawn directly by the local residents under the form of fuelwood and other miscellaneous products [56]. From an economic point of view, the forestry sector provides $30 \%$ coverage of the country's needs in timber and industry $\left(600,000 \mathrm{~m}^{3}\right.$ of timber and industrial timber and $129,500 \mathrm{~m}^{3}$ of cork per year). In addition, forests contribute $30 \%$ to the overall energy balance at the national level [57].

In northern Morocco, silvopastoral resources play a considerable socio-economic function. In addition to fodder supply, these resources allow the population to draw most of its fuel. They also represent a significant contribution to household income through the exploitation of non-wood forest products, aromatic plants and medicinal products used in the pharmaceutical and cosmetic industries, honey, lichen, mushrooms, and hunting and fishing products [58]. In fact, forest products for domestic use, such as fuelwood and firewood, rangelands, and service wood mobilize considerable volumes of products that concern essentially all the forest areas of the Rif massifs. The population distinguishes the small forest used as a land reserve for practicing agriculture from the large forest used more for rangelands and wood harvesting. Overall, it is the matorral and scrubland formations made up of so-called secondary species that are more accessible, which mostly meet the domestic needs of the rural populations [50].

The social function of silvopastoral areas is expressed through the jobs, income, and uses of local residents recognized by forestry legislation, recreational activities, and leisure. 
To fully understand the socio-economic importance of the Rif forest and according to the available data, we took the forest area of the western Rif as an example, one of the most important areas in the study region. This forest area offers more than 200,000 working days, guaranteeing employment throughout the year for an average workforce of 800 workers. The production is composed of timber $\left(310 \mathrm{~m}^{3} /\right.$ year), industrial and service timber (9340 $\mathrm{m}^{3}$ /year), fuelwood and firewood (19,800 $\mathrm{m}^{3} /$ year), cork (8150 steers/year), and heather strains $(860 \mathrm{q} /$ year). These productions provide revenue for rural communities that amounts on average to almost 568,000 euros annually. In addition to forest products, the forest offers significant landscaping and floristic diversity for developing and promoting tourism and hunting [50].

\section{Pastoral function}

In northern Morocco, shrub and tree species constitute the main food resources of grazing goats. In these mountainous pastures, goats show great plasticity. Their numbers are greater in the provinces of Tetouan (54\%) and Chefchaouen (45\%) compared to the rest of the animals. The profitability of goat farming, the available silvopastoral resources, and the ingestion of many woody species explain this importance [59]. The topography and ligneous vegetation limit the grazing of sheep and cattle in forest rangelands. Sheep and cattle farms are generally located in low-altitude areas, more particularly in Tangier and Loukkos, where a very large amount of agricultural land can be found. These ruminants are mostly reared in the agropastoral system inside medium and large farms with more fodder resources from agriculture away from forest rangeland, where agricultural lands are uncommon [30]. The number of goats in northern Morocco fluctuates over the years (Figure 4) depending on drought periods and herder motivation [60]. There are about 627,000 heads, mainly localized in the silvopastoral and mountainous areas [61].

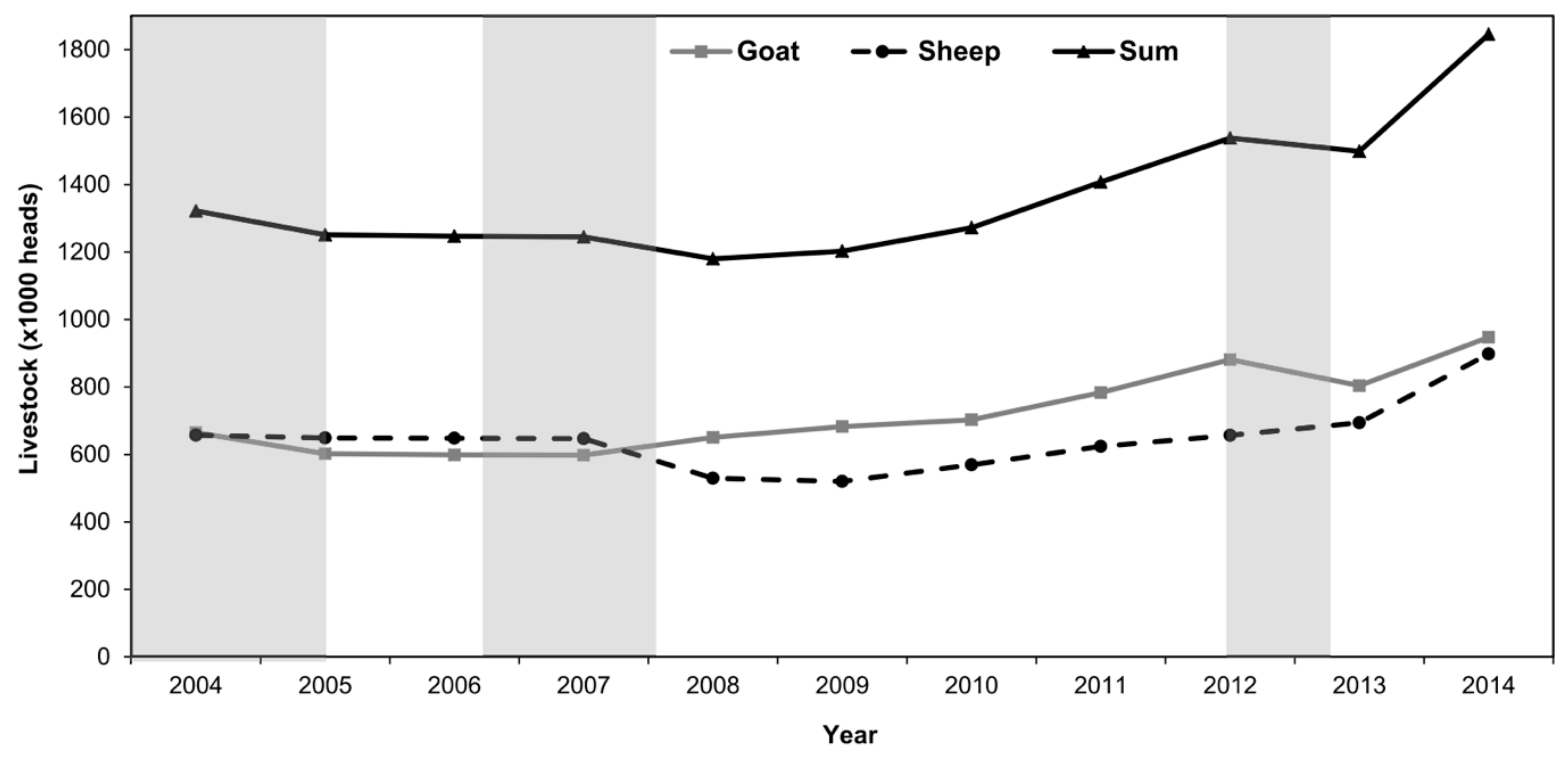

Figure 4. Population changes of goats and sheep in northern Morocco between 2004 and 2014 [30]. Note: Drought periods indicated with a gray background.

During the dry season and low forage availability, herders move their flocks considerable distances to other forest pastures to ensure regular feeding and thus limit the costs that arise due to feed supplementation. Meat goat production, compared to dairy goats, is still largely dominant in northern Morocco, with silvopastoral resources as the only feed source [31]. In general, farmers prefer that goats spend more time in the forest in order to avoid feed supplementation [30].

Silvopastoral areas ensure an appreciable and free forage production for grazing animals. Regarding the pastoral importance of these areas, several studies have been 
carried out within the framework of the regional research program of the National Institute of Agricultural Research (INRA), in order to assess the forage availability of forest rangeland in northern Morocco (Figure 5). Forage availability varied between 373 and $2300 \mathrm{~kg} \mathrm{DM} / \mathrm{ha}$ depending on the studied forest rangelands. In western Rif (Chefchaouen), the forage availability of forest rangeland covered by oak cork varied seasonally from 1018 to $2590 \mathrm{~kg} \mathrm{DM} / \mathrm{ha}$ [59].

Grazing is practiced from mid-winter until autumn. Indeed, during this period of the year, the rangelands are in the phase of reconstituting their vegetal cover with a maximum forage availability recorded during spring [59]. Goats spend most of the day in the forest rangeland. During winter, a period of heavy rains, the grazing intensity decreases. Goats graze fallow land around the farm because of difficult access to the pastures [26].

Goat farming plays a very important economic role for farmers in the southern Mediterranean forest rangeland of northern Morocco. The economic importance of goat farming is clearly reflected in its contribution to household income generation. It varies from $68 \%$ among meat producers to $100 \%$ among milk producers without agricultural land. This proportion is about 78\% in mixed farms with agricultural land and dairy farms [62].

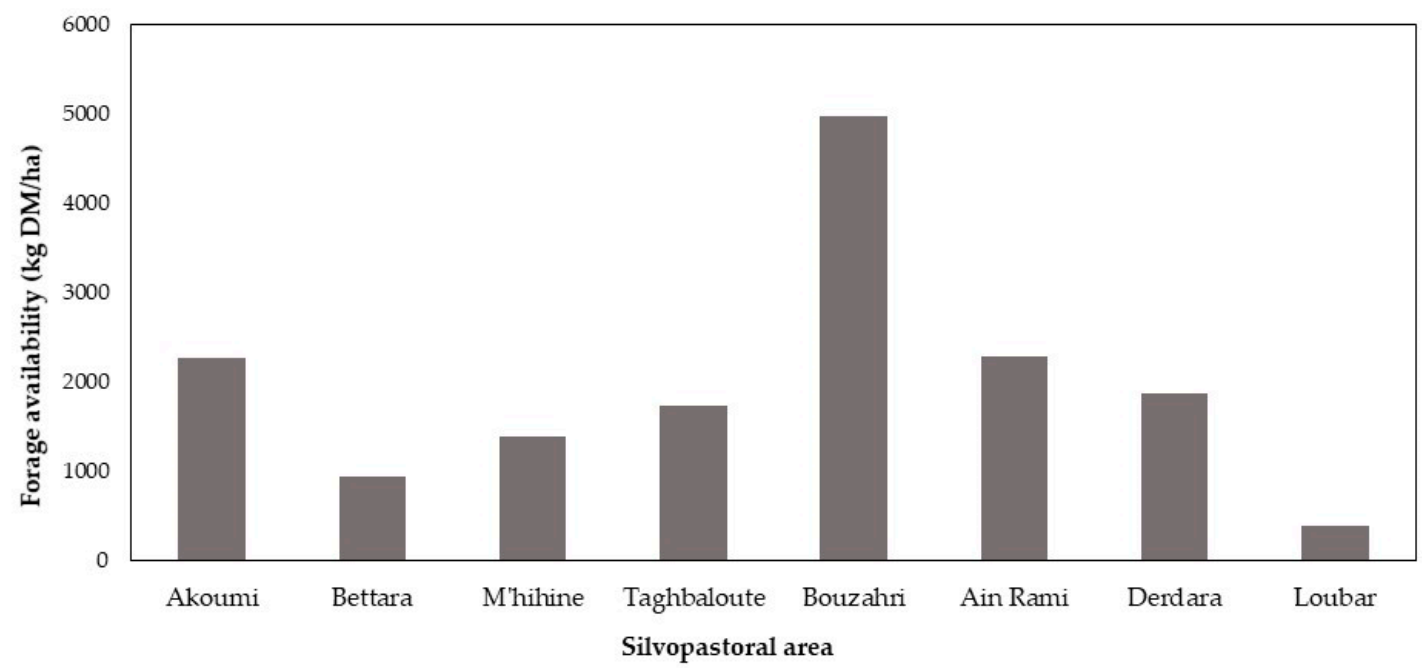

Figure 5. Forage availability of different silvopastoral areas in northern Morocco [31,63].

While they are very diverse, silvopastoral areas are characterized by a production level that does not reflect their enormous pastoral potential. This situation is explained by alarming degradation due to the combination of several degradation drivers [30].

\subsubsection{Silvopastoral Area Changes and Its Drivers}

During the last 30 years, forest and silvopastoral areas of northern Morocco have undergone profound changes and transitions in their land use-land cover (LULC). The most significant changes indicate a clear decline in vegetation cover of around $25 \%$ [30]. This recent study revealed that most of the observed transitions concerned the forest and silvopastoral areas (Figure 6). These areas have gradually been converted into matorrals (158,690 ha), cultivated land (33,270 ha), bare/built-up land (62,540 ha), and water reservoirs (4535 ha). Only 65,100 ha of matorrals and 1000 ha of bare/built-up land have been rehabilitated into forest and silvopastoral areas (reforestation and natural regeneration). Agricultural expansion at the expense of the silvopastoral areas has been confirmed by several studies $[30,37,64]$. Shifting crops (cannabis cultivation and cereal cultivation), which often require new fertile land, are designated as the main drivers of this degradation $[30,45,65]$. Cannabis cultivation causes an annual loss of 1000 ha of forest and silvopastoral areas [66]. The construction of seven large dams between 1980 and 2003 favored the development of intensive agriculture, as the irrigated areas increased by $210 \%$ during the last three decades [30]. In addition to the agricultural expansion, forest fires 
have greatly contributed to the degradation of silvopastoral areas. It was reported that $65 \%$ of nationwide forest fires are concentrated in northern Morocco, which represents a loss of 1185 ha per year [67]. On the other hand, the estimated harvest of wood for fuel extraction exceeds the potential of forest production by 2.5 times [50]. Forest delimbing is a very widespread activity in northern Morocco. This uncontrolled practice engenders damages in the silvopastoral area [60]. Forest degradation intensifies soil erosion, inducing intense regression of woodlands and restraining regeneration of vegetation [68,69]. In addition, population growth causes an increased demand for land and resources, which explains the huge pressure on available natural resources, mainly forest and silvopastoral areas $[30,70,71]$. In general, the alarming degradation of forest and silvopastoral areas observed is due to the combination of both climatic and anthropic drivers [30].

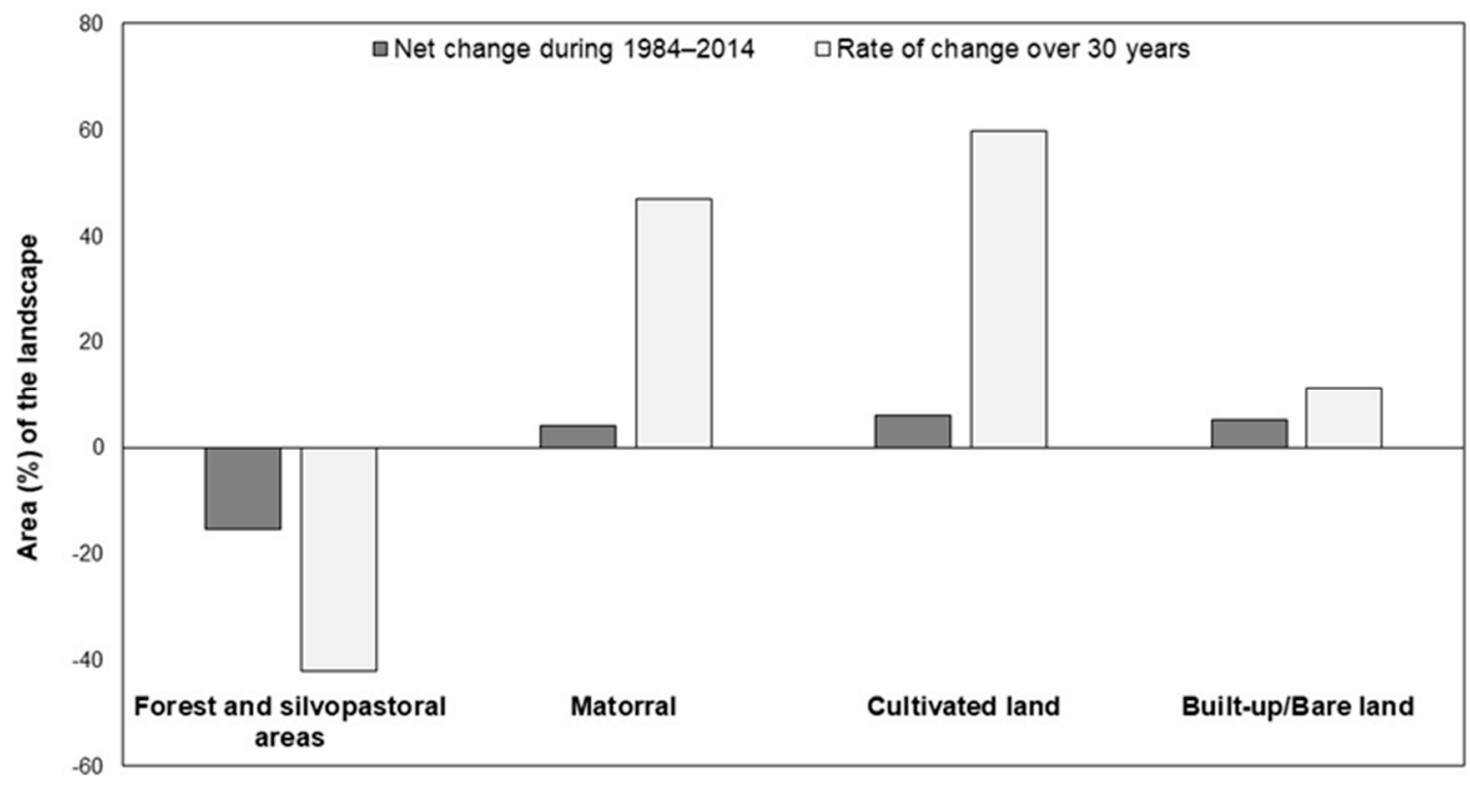

Figure 6. Land cover change in the Mediterranean region of northern Morocco between 1984 and 2014 [30].

\subsection{Crucial Sustainable Development Actions}

In order to support sustainable management actions of silvopastoral resources, there are several strategies and propositions that could be more encouraged:

- Generate alternative sources of income for local populations: Developing other economic activities such as ecotourism to reduce pressure on silvopastoral areas;

- Use of available renewable energy technologies, i.e., solar and wind power, to reduce deforestation;

- Silvopastoral rehabilitation of degraded areas: Planting fodder shrubs will contribute to increase short-term and medium-term fodder production and to reduce the impact on rangelands;

- Management of forest defenses (protection): Sustainable management of forests cannot be guaranteed unless defending and regenerating options are considered over a certain period depending on the forest species. The purpose is to save the forest without neglecting the interests of users. The efforts to be undertaken aim to reconcile the shortand medium-term productive and economic benefits of extensive livestock farming systems and the long-term sustainable management of silvopastoral resources;

- The participatory approach can also be applied through the involvement of user breeders in the self-development process and the creation of basic socio-economic infrastructures likely to enhance grazing and forest exploitation practices;

- A tax for forest grazing must be implemented. It should be proportional to the herd size and farmer's financial situation. The collected taxes should be reinvested in silvopastoral rehabilitation. 


\section{Conclusions}

The silvopastoral systems in Morocco, which combine trees, herbaceous resources, and livestock on the same unit of land, are a socio-economically and ecologically productive alternative to traditional management systems. Successful silvopastoral systems require effective limitation of agricultural expansion and deforestation phenomena, which could preserve the beauty and diversity of the landscape.

Nowadays, most of these systems are facing great difficulties as the world's forests deteriorate. This situation is explained by an alarming degradation due to the combination of both climatic and anthropic drivers. The present condition of Moroccan silvopastoral areas, especially in the southern Mediterranean region of northern Morocco, is complex. In order to ensure the sustainability of these resources, decision-makers must further develop appropriate policies and strategies that boost management and restoration actions for different users engaged in sustainable silvopastoral systems.

Future studies should assess the actual damage and degradation of the Moroccan silvopastoral system, as an integral part of the Mediterranean region, due to anthropogenic use under the impact of climate change. Likewise, Mediterranean countries need to combine their efforts in order to reduce this damage and assess the realistic socio-economic and ecological benefits of silvopastoral systems to promote their sustainable development and to ensure sound investments.

Author Contributions: Y.C. is responsible for the main body of text drafting, data collection, and analysis. S.E.O., M.C., F.E., N.M., J.-L.H. and J.-F.C. contributed equally in some sections in the first draft. Y.C. structured the writing of the original draft manuscript. All authors have read and agreed to the published version of the manuscript.

Funding: This project received funding from the Academy for Research and Higher EducationDevelopment Cooperation Committee (ARES-CCD), Brussels, Belgium. This study is realized in the framework of the Research Project for Development: PRD (2013-2018).

Institutional Review Board Statement: Not applicable.

Informed Consent Statement: Not applicable.

Data Availability Statement: Not applicable.

Acknowledgments: The authors would like to thank the Research for Development Project (PDR) and INRA collaborators.

Conflicts of Interest: The authors declare no conflict of interest.

\section{References}

1. Gomes, F.J.; Pedreira, B.C.; Santos, P.M.; Bosi, C.; Lulu, J.; Pedreira, C.G.S. Microclimate effects on canopy characteristics of shaded palisadegrass pastures in a silvopastoral system in the Amazon biome of central Brazil. Eur. J. Agron. 2020, 115, 126029. [CrossRef]

2. Papanastasis, V.P. Silvopastoral systems and range management in the Mediterranean region. In Western European Silvopastoral Systems; Etienne, M., Ed.; FAO: Rome, Italy, 1996; pp. 143-156.

3. San Miguel, A. Gestión silvopastoral y conservación de especies y espacios protegidos. In Pastos, Desarrollo y Conservación; Robles, A.B., Ramos, M.E., Morales, M.C., Simón, E., González-Rebollar, J.L., Boza, J., Eds.; Junta de Andalusia: Granada, Spain, 2003; pp. 409-422.

4. Robles, A.B. The Mediterranean pastures and silvopastoral systems: Basic concepts. In Agroforestry Systems as a Technique for Sustainable Land Management; Mosquera-Losada, M.R., Fernández-Lorenzo, J.L., Rigueiro-Rodríguez, A., Eds.; Unicopia Ediciones; AECID: Madrid, Spain, 2009; pp. 59-69.

5. Casals, P.; Baiges, T.; Bota, G.; Chocarro, C.; de Bello, F.; Fanlo, R.; Sebastia, M.T.; Taull, M. Silvopastoral systems in the Northeastern Iberian Peninsula: A multifunctional perspective. In Agroforestry in Europe: Current Status and Future Prospects; Rigueiro-Rodrı'guez, A., McAdam, J., Mosquera-Losado, M., Eds.; Springer Science and Business Media B.V.: Dordrecht, The Netherlands, 2009; pp. 161-182.

6. Linares, A.M. Forest planning and traditional knowledge in collective woodlands of Spain: The dehesa system. For. Ecol. Manag. 2007, 249, 71-79. [CrossRef]

7. Moher, D.; Liberati, A.; Tetzlaff, J.; Altman, D.G. Preferred Reporting Items for Systematic Reviews and Meta-Analyses: The PRISMA Statement. PLoS Med. 2009, 6, e1000097. [CrossRef] [PubMed] 
8. Kimmins, J.P. Ecosystem management and landscape ecology: The ultimate focus in forest ecology. In Forest Ecology. A Foundation for Sustainable Forest Management and Environmental Ethics in Forestry, 3rd ed.; Chapter 19; Prentice Hall: Upper Saddle River, NJ, USA, 2003.

9. FAO (Food and Agriculture Organization of the United Nations). Base des Données Statistiques de la FAO (FAOSTAT). 2011. Available online: http:/ / www.fao.org/faostat/fr/\#data (accessed on 20 April 2021).

10. PAPFM (Programme Additionnel au Programme D'appui à la Politique Forestière au Maroc). ANNEXE I de la Décision D'exécution de la Commission Relative au Programme D'action Annuel-Partie 2. 2017. Available online: https://www.gtai.de/ resource/blob/40862/537dbabfc9d88bfadadf55e75b475f4e/pro201711175004-data.pdf/ (accessed on 20 April 2021).

11. Baguare, A. Evaluation de L'approche Participative en Matière de Gestion Forestière. Cas de la Commune Rurale Oued Ifrane; Rapport de Recherche; ONDH: Rabat, Morocco, 2013; 112p.

12. Faouzi, H. The Agdal in the dynamics of farming fystems of the Haha (western High Atlas, Morocco). Etudes Caribéennes 2011, 20, 5569. [CrossRef]

13. Hammi, S.; Simonneaux, V.; Alifriqui, M.; Auclair, L.; Montes, N. Evolution of forest and land coverage from 1964 to 2002 in the high valley of Ait Bouguemez (Central High Atlas, Morocco). Impact of management modes. Sécheresse 2007, 18, 271-277.

14. Auclair, L.; AlIfriqui, M. Les agdals du Haut Atlas marocain. Enjeux d'une recherche pluridisciplinaire. Cah. Rech. Cent. Jacques Berque 2005, 3, 61-79.

15. Poupon, J. L'aménagement et l'amélioration des parcours forestiers au Maroc 2 ème Partie. Forêt Méditerranéenne 1980, 1, 53-60.

16. Pérez León, N.; Bruzzone, O.; Easdale, M.H. A framework to tackling the synchrony between social and ecological phases of the annual cyclic movement of transhumant pastoralism. Sustainability 2020, 12, 3462. [CrossRef]

17. Venema, B.; Mguild, A. The vitality of local political institutions in the middle atlas, Morocco. Ethnology 2002, 41, 103-117. [CrossRef]

18. MAPM (Ministère de l'Agriculture, de la Pêche Maritime). Deuxième Rapport National sur L'état des Ressources Génétiques Animales Royaume du Maroc; MAPM: Rabat, Morocco, 2014.

19. Pattanayak, S.K.; Mercer, D.E.; Sills, E.; Yang, J.C. Taking stock of agroforestry adoption studies. Agrofor. Syst. 2003, 57, 173-186. [CrossRef]

20. Montagnini, F. Management for sustainability and restoration of degraded pastures in the Neotropics. In Post-Agricultural Succession in the Neotropics; Myster, R., Ed.; Springer: New York, NY, USA, 2008; pp. 265-295.

21. Calle, A.; Montagnini, F.; Zuluaga, A.F. Farmer's perceptions of silvopastoral system promotion in Quindío, Colombia. Bois Forêts Trop. 2009, 300, 79-94. [CrossRef]

22. Naggar, M. Stratégie sylvopastorale et renouveau des pratiques pastorales en forêt au Maroc. Rev. For. Française 2018, 70, 487-501. [CrossRef]

23. Naggar, M. Eléments de base d'une stratégie de sylvopastoralisme en Afrique du Nord. Options Méditerranéennes 2000, 39, 191-202.

24. Naggar, M. Le parcours en forêt et l'aléa climatique-Un enjeu d'écologie social? In Proceedings of the XII World Forestry Congress, Québec City, QC, Canada, 21-28 September 2003.

25. Naggar, M. La question pastorale et les enjeux de la gouvernance territoriale de l'arganeraie. Espace Géograph. Société Maroc. 2019, 30, 5-12.

26. Chebli, Y.; El Otmani, S.; Chentouf, M.; Hornick, J.-L.; Cabaraux, J.-F. Temporal variations in chemical composition, in vitro digestibility, and metabolizable energy of plant species browsed by goats in southern Mediterranean forest rangeland. Animals 2021, 11, 1441. [CrossRef] [PubMed]

27. Chentouf, M.; Arrebola Molina, F.; Boulanouar, B.; Mesbahi, H.; Terradillos, A.; Caravaca, F.; Casas, C.; Bister, J.L. Caractérisation des systèmes de production caprine semi-extensifs en Andalousie et au Nord du Maroc: Analyse comparative. Options Méditerranéennes 2009, 91, 37-42.

28. Chentouf, M.; Boulanouar, B.; Bister, J.L. Elevage caprin au Nord du Maroc; INRA-Editions Press: Rabat, Morocco, 2015; 168p.

29. Mahdi, M. Pasteur de l'Atlas: Production pastorale, droit et rituel, Casablanca. Fondation Konrad Adenauer. Études Rural. 1999, 159-160. [CrossRef]

30. Chebli, Y.; Chentouf, M.; Ozer, P.; Hornick, J.L.; Cabaraux, J.F. Forest and silvopastoral cover changes and its drivers in northern Morocco. Appl. Geogr. 2018, 101, 23-35. [CrossRef]

31. Chebli, Y.; Chentouf, M.; Hornick, J.L.; Cabaraux, J.F. Extensive goat production systems in northern Morocco: Production and use of pastoral resources. In Grassland Resources for Extensive Farming Systems in Marginal Lands: Major Drivers and Future Scenarios; Porqueddu, A., Franca, C., Lombardi, A., Molle, G., Peratoner, G., Hopkins, G., Eds.; Wageningen Academic Publishers Press: Wageningen, The Netherlands, 2017; pp. 131-133.

32. Gillet, F.; Peringer, A. Dynamic modelling of silvopastoral landscape structure: Scenarios for future climate and land use. In Managing Resources of a Limited Planet, Proceeding of the International Congress on Environmental Modelling and Software, 6th Biennial Meeting, Leipzig, Germany, 1-5 July 2012; Seppelt, R., Voinov, A.A., Lange, S., Bankamp, D., Eds.; International Environmental Modelling and Software Society: Manno, Switzerland, 2012.

33. Peringer, A.; Siehoff, S.; Chételat, J.; Spiegelberger, T.; Buttler, F. Gillet. Past and future landscape dynamics in pasture-woodlands of the Swiss Jura Mountains under climate change. Ecol. Soc. 2013, 18, 11. [CrossRef] 
34. Moukrim, S.; Lahssini, S.; Rhazi, M.; Mharzi Alaoui, H.; Benabou, A.; Wahby, I.; El Madihi, M.; Arahou, M.; Rhazi, L. Climate change impacts on potential distribution of multipurpose agro-forestry species: Argania spinosa (L.) Skeels as case study. Agroforest. Syst. 2019, 93, 1209-1219. [CrossRef]

35. Elame, F.; Doukkali, R.; Lionboui, H. Dynamic modeling of climate change impact on agricultural lands and water resources. In Handbook of Climate Change Management; Leal Filho, W., Luetz, J., Ayal, D., Eds.; Springer: Cham, Switzerland, 2020 ; pp. 1-21. [CrossRef]

36. Ait Brahim, Y.; Seif-Ennasr, M.; Malki, M.; N'da, B.; Choukrallah, R.; El Morjani, Z.E.A.; Sifeddine, A.; Abahous, H.; Bouchaou, L. Assessment of climate and land use changes: Impacts on groundwater resources in the Souss-Massa River Basin. In The SoussMassa River Basin, Morocco. The Handbook of Environmental Chemistry; Springer: Cham, Switzerland, 2016; Volume 53, pp. 121-142. [CrossRef]

37. Tramblay, Y.; Ruelland, D.; Somot, S.; Bouaicha, R.; Servat, E. High-resolution Med-CORDEX regional climate model simulations for hydrological impact studies: A first evaluation of the ALADIN-Climate model in Morocco. Hydrol. Earth Syst. Sci. 2013, 17, 3721-3739. [CrossRef]

38. FAO (Food and Agriculture Organization of the United Nations). Rapport National du Maroc. Forêts, Parcours et Changement Climatique Dans la Région du Proche Orient, le Caire. 20-22 September 2011. Available online: http://www.fao.org/forestry/29 290-019a95bbd8583bf54d5b1f62639881cf0.pdf (accessed on 20 April 2021).

39. Elame, F.; Doukkali, R.; Fadlaoui, A. Modélisation économique de l'impact des changements climatiques sur les ressources en eau. Newmedi 2016, 15, 10-18.

40. Ilmen, R.; Benjelloun, H. Les écosystèmes forestiers marocains à l'épreuve des changements climatiques. Forêt Méditerranéenne 2013, 3, 195-208.

41. M’hirit, O.; Benzyane, M.; Benchekroun, F.; El Yousfi, S.M.; Bendaanoun, M. L'arganier, une Espèce Fruitière-Forestière à Usages Multiples; Mardaga: Sprimont, Belgique, 1998; 145p.

42. Zeino-Mahmalat, E.M.; Bennis, A. Environnement et changement climatique au Maroc-Diagnostic et Perspectives, 1st ed.; KonradAdenauer-Stiftung: Rabat, Morocco, 2012; 90p.

43. MAPMDREF (Ministère de L'Agriculture, de la Pêche Maritime, du Développement Rural et des Eaux et Forêts). Forêts en Chiffre. Département des Eaux et Forêts. 2018. Available online: http:/ / www.eauxetforets.gov.ma/ForetsMarocaines/ForetsChiffres / Pages/Forets-En-Chiffres.aspx (accessed on 20 April 2021).

44. Mediani, M.; Brito, J.C.; Fahd, S. Atlas of the amphibians and reptiles of Northern Morocco: Updated distribution and patterns of habitat selection. Basic Appl. Herpetol. 2015, 29, 81-107. [CrossRef]

45. Grovel, R. La préservation des forêts du Rif centro-occidental: Un enjeu de développement de la montagne rifaine. Rev. Géograph. Alp. 1996, 4, 75-94. [CrossRef]

46. Quezel, P.; Barbero, M.; Loisel, R. Les reboisements en région méditerranéenne. Incidences biologiques et économiques. Forêt Méditerranéenne 1990, 2, 103-114.

47. Taiqui, L. La dégradation écologique au Rif marocain: Nécessités d'une nouvelle approche. Mediterranea 1997, 16, 5-17. [CrossRef]

48. Benabid, A. Ecologie, Conservation et Restauration des Subéraies; Formation Continue à l'ENFI: Salé, Morocco, 1989.

49. Albergel, J.; Collinet, J.; Zante, P.; Hamrouni, H. Role of the Mediterranean forest in soil and water conservation. In Water for Forests and People in the Mediterranean Region: What Science Can Tell Us?; Birot, Y., Garcia, C., Palahi, M., Eds.; European Forest Institute: Joensuu, Finland, 2011; pp. 46-56.

50. SPEF (Service Provincial des Eaux et Forêts). Potentialité et problématique forestière dans la province de Chefchaouen. In Rapport du Haut-Commissariat aux Eaux et Forêts et à la Lutte Contre la Désertification; SPEF: Chefchaouen, Morocco, 2006.

51. Sabir, M.; Barthes, B.; Roose, E. Recherche d'indicateurs de risques de ruissellement et d'érosion sur les principaux sols des montagnes méditerranéennes du Rif occidental (Maroc). Sci. Chang. Planétaires Sécheresse 2004, 15, $105-110$.

52. Matteucci, G.; Vanclay, J.; Martin-Vide, J. Do forest areas influence rainfall regime? In Water for Forests and People in the Mediterranean Region: A Challenging Balance; Birot, Y., Garcia, C., Palahi, M., Eds.; European Forest Institute: Joensuu, Finland, 2011; pp. 32-36.

53. Dupouey, J.L.; Pignard, G.; Hamza, N. La séquestration de carbone en forêt. Forêt-Entrep. 2006, 168, 15-18.

54. FAO (Organisation des Nations Unies pour l'alimentation et l'agriculture). Situation des Forêts du Monde; FAO: Italy, Rome, 2011; 176p.

55. Qarro, M.; Berkat, O.; M’Hamedi, M.; Yessef, M. L'aménagement sylvopastoral: Contraintes et développement durable. In Rupture: Nouveaux Enjeux, Nouvelles Fonctions, Nouvelle Image de L'élevage sur Parcours; Bourbouze, A., Qarro, M., Eds.; CIHEAM-IAMM: Montpellier, France, 2000; pp. 171-174.

56. HCEFLCD (Haut-Commissariat Eaux et Forêts et Lutte Contre la Désertification). Forêts en Chiffres. 2007. Available online: http: / / www.eauxetforets.gov.ma/fr/text.aspx?id=1035uid=53 (accessed on 20 April 2021).

57. AEFCS (Administration des Eaux et Forêts et Conservation des sols). Actes du Colloque National sur la Forêt, du 21 au 23 Mars à Ifrane; AEFCS: Rabat, Maroc, 2012.

58. Hammoudi, A. Subéraie et Biodiversité du Paysage; Rapport Présenté à Vivexpo; Institut Méditerranéen du Liège: Vivès, France, 2002; 5 p.

59. Chebli, Y.; El Otmani, S.; Chentouf, M.; Hornick, J.-L.; Bindelle, J.; Cabaraux, J.-F. Foraging behavior of goats browsing in southern Mediterranean forest rangeland. Animals 2020, 10, 196. [CrossRef] 
60. Chebli, Y.; Chentouf, M.; Mrabet, R.; Keli, A. Production et utilisation des parcours dans les montagnes rifaines du nord du Maroc. Options Méditerranéennes 2014, 108, 109-113.

61. DRATT (Direction Régionale de l'Agriculture de Tanger-Tétouan). Monographie de la Région du nord du Maroc. Rapports et Données Statistiques sur L'agriculture et L'élevage. 2017. Available online: http:/ /www.dratt.ma/ (accessed on 20 April 2021).

62. Chentouf, M.; Zantar, S.; Doukkali, M.R.; Farahat, L.B.; Jouamaa, A.; Aden, H. Performances techniques et économiques des élevages caprins dans le nord du Maroc. Options Méditerranéennes 2011, 100, 151-156.

63. Chebli, Y.; Mrabet, R. Les ressources pastorales dans le domaine rifain. In L'élevage caprin au nord du Maroc; Chentouf, M., Boulanouar, B., Bister, J.L., Eds.; INRA-Editions Press: Rabat, Morocco, 2014; pp. 64-79.

64. Aubert, P.M. Les évolutions de la politique forestière au Maroc: Entre réappropriation du modèle forestier français et idéalisation de la tribu. Rev. For. Française 2013, 4, 305-316. [CrossRef]

65. Benabid, A. Le Rif et le Moyen Atlas (Maroc): Biodiversité, menaces, préservation. In Proceedings of the Mountains High Summit Conference for Africa, Nairobi, Kenya, 6-10 May 2002.

66. Labrousse, A.; Romero, L. Rapport sur la situation du cannabis dans le Rif marocain Observatoire Français des Drogues et des Toxicomanies (OFDT) et Centre d'Etude Rurale et d'Agriculture Internationale (CERAI). 2001. 23p. Available online: https:/ / www.ofdt.fr/BDD/publications/docs/epbxalhc.pdf (accessed on 20 April 2021).

67. Mharzi Alaoui, H.M.; Assali, F.; Rouchdi, M.; Lahssini, S.; Tahiri, D. Analyse de l'interaction entre l'éclosion des feux de forêts et les types de bioclimat au Nord du Maroc-Cas de la région du Rif occidental. Rev. Maroc. Sci. Agron. Vét. 2015, 3, 46-53.

68. Raissouni, A.; Issa, L.K.; Arrim, A.; El Maâtouk, M.; Passalacqua, R. GIS-based model to assess erosion sensitivity in northern Morocco. Laou watershed case study. J. Geosci. 2012, 3, 610-626. [CrossRef]

69. Sadiki, A.; Bouhlassa, S.; Auajjar, J.; Faleh, A.; Macaire, J.J. Utilisation d'un SIG pour l'évaluation et la cartographie des risques d'érosion par l'équation universelle des pertes en sol dans le Rif oriental (Maroc): Cas du bassin versant de l'oued Boussouab. Bull. L'institut Sci. 2004, 26, 69-79.

70. HCP (Haut-Commissariat au Plan). Monographie Régionale de Tanger-Tétouan. 2014. Available online: https://www.hcp.ma/ region-tanger/attachment/823725/ (accessed on 20 April 2021).

71. Afsahi, K.; Darwich, S. Hashish in Morocco and Lebanon: A comparative study. Int. J. Drug Policy. 2016, 31, 190-198. [CrossRef] [PubMed] 